\title{
Globalisation's Ugly Stepsister: Estimating Some Economic Impacts of Localisation in South Africa
}

\author{
Marthinus C Breitenbach, University of Pretoria, Gauteng, SOUTH AFRICA \\ Tielman JC Slabbert, North-West University, SOUTH AFRICA
}

\begin{abstract}
There is growing concern that globalisation is unable to address unemployment and alleviate poverty sufficiently to achieve the targets of the Millennium Development Goals. Increasing numbers of development economists and practitioners advocate some or other policy favouring the localisation of economic activity in local communities. The authors' research and policy impact analysis are rooted in the sincere belief that localisation, as defined in this paper, is required alongside globalisation, if the Millennium Development Goals are to be met. The authors explain to the reader that localisation encompasses the institutionalisation of policy execution within specific localities (local township communities). Localisation is thus not a new policy per se, but a policy of institutionalising the localisation of existing government policy and programmes. This paper reflects the authors' estimate of the regional economic impact of a localisation policy, using a case study from South Africa. Alternative strategies are required for the unemployed poor to participate in economic activity. This is usually done by encouraging the unemployed to engage in informal sector entrepreneurial and self-employment activities, which do not contribute much towards building working local economies, as they often take place in the services sector and in a geographic location within the formal economy. The authors investigate the postulate that working local economies can be achieved if the unemployed poor engage in production of the commodities most needed within their own local community. This can be achieved by applying the factors of production present within said community. The authors marry the consumer needs of the local economies with their stock of production factors (available skills) and estimate the number of people that could be gainfully employed, together with the impact of localisation on poverty levels. Input-Output Policy Impact Assessment models show that an additional gross output of R953.28 million could be created annually within the (local) township economy if current consumption expenditure and production activity is localised. Similar results may be obtained by localising government transfers such as social welfare contributions and public works programmes.
\end{abstract}

Keywords: Globalisation, Localisation, Economic Impact Assessment, Poverty, Unemployment, Input-Output model

\section{Introduction}

$\mathrm{D}$ URING THE LAST twenty years, national economies have become increasingly interlinked through the international market for goods and services and factors of production, which gave rise to a highly integrated world economy (Nayyar, 2002). This is described as globalisation. Academia, policy makers and development practitioners generally accept that globalisation is one of the most critical developments impacting on the growth of national economies (Helleiner, 2001).

Globalisation offers opportunities for accelerated economic growth and development, but at the same time poses challenges. Whereas the benefits of globalisation are significant, it is questionable to which extent the distribution of gain is fair. Basu (2003) contends that the poor in developing countries benefit proportionately less from globalisation and that the downside risk for developing economies is rather severe during global financial and economic crises.

Globalisation is not immune to market failure and cannot eliminate problems of unemployment and poverty. Whereas some developing economies have been harmed by globalisation and others have benefited, communities located within these economies have been left behind by globalisation (UNDP, 2007).

The authors do not intend to initiate a debate on who benefited from globalisation and who not. Instead, this paper argues the point of view that certain communities within national economies favoured by globalisation have been left behind by it. Furthermore the authors depart from the premise that globalisation has been harmful to local communities insofar as global growth had been associated with changes in technology which favoured mechanised production at the expense of labour intensive production. For many local community members, economic opportunities have been destroyed as a result of jobless growth (and often job-destructive growth) associated with globalisation. Current policies and programmes are not an effective remedy for large scale structural unemployment and poverty. This calls for a critical analysis of not only current policy initiatives, but also new ones. Stimulated by their interest in local economic development policies, Van Zyl and Reyn- 
olds (2006) undertook extensive studies in local communities in South Africa.

Van Zyl and Reynolds (2006) spent many years studying local economies and the working of markets in local communities. At the time of their untimely passing, they had been running pilot studies in certain local communities around South Africa and had been advising South Africa's Department of Provincial and Local Government (DPLG) on its policy of Sustainable Local Economic Development. These development economists both held the view that most local community members in South Africa sell their labour outside their own communities in the formal sector of the economy and likewise spend most of their earnings outside their local community. Reynolds (2004) estimated local community multipliers in townships of South Africa to be around unity (one). Van Zyl and Reynolds (2006) found that local communities in South Africa had been harmed by globalisation. They strongly believed that the solution was to be found in a policy of localisation of economic activity within local (township) communities through meaningful intervention. This policy was not regarded as being in conflict with globalisation, but as being complementary thereto. Some of the most latent principles associated with the localisation of economic activity upheld by Van Zyl and Reynolds were included in a DPLG (2007) policy document entitled: "Sustainable Local Economic Development". This attempt by the authors is the first to illustrate how such a policy would work and what its expected impact would be.

Localisation is a generic term that refers to limiting something to a specified locality. In this paper, the authors use the term localisation very specifically to refer to the act of shifting (or limiting) economic activity to a specific locality. A local economy is a geographical urban or rural area in which communities have been settled and is proclaimed as local government area. In South Africa, the residential areas that had historically been earmarked for settlement of people from the black, coloured and Indian races are by convention referred to as townships. These localities were also frequently referred to as locations, e.g. a black location was the term used to describe a local area demarcated for settlement of black people. In this paper, the authors may on occasion use the terms "township" and "local communities" interchangeably.

In South Africa, township communities are often poor and economic activity largely commutes to adjacent areas in the formal sector of the economy. Communities sell their labour and earn their wages in the formal sector economy. They also largely spend their income in the adjacent formal sector economy or on goods and services produced in the formal sector economy.
Very little economic activity takes place within local communities. By contrast, local communities with higher income and wealth attract many production, consumption and service sector activities and employ large numbers of labourers (skilled, semiskilled and low-skilled). Many high income business owners also prefer to locate business activities within their own community.

In this paper, the authors illustrate the policy impact of localisation for South Africa. The paper is thus meant to introduce and stimulate research and debate on a policy of localisation. The reader is forewarned that a policy of localisation, although partly derived from the word local in Local Economic Development (LED), is an overarching policy of institutionally localising economic activity and government policy in local communities where there is a real need, in other words those communities with the highest levels of unemployment and poverty.

A policy of localisation is dimensionally local as opposed to spatially developmental and differs in many respects from the spatial Integrated Development Plans (IDPs) and LED. Localisation policy should therefore be understood to include the government's intervention through appropriate plans and programmes of action to institutionalise the localisation of some gainful economic activity in poor communities. Many policies and programmes designed by government would augur well to develop local communities in South Africa - chief among them government-assisted Small and Medium Enterprise (SME) and cooperative development schemes. These are generally well-intended and well-designed and simply require being redirected to localities within deprived and poor local communities.

Government thus has the right intent. What is required is a critical analysis of the HOW of the execution of specific programmes. This paper investigates local communities of a specific region to ascertain their economic status. Additional evidence about supply and demand of these townships was obtained by means of a survey. Unemployment and poverty, as well as some other important socio-economic information about these local communities, were assessed. This provided the researchers with information on the untapped idle resources (mostly semiskilled unemployed labour) available to these communities. The authors then used impact assessment models to illustrate the impact of a policy of localisation on production, consumption and, mostly, output (income).

The paper is organised as follows: the next section provides the reader with a background to the local community chosen for the analysis and its regional setting. The second part of the background provides further justification for the study from a policy perspective. The third section outlines the methodology 
for assessing the policy impact. The paper concludes with the results of the policy impact assessment and a summary.

\section{Background of the Local Community Chosen for the Study}

\section{The Household Survey}

A household survey was conducted to supplement Census data, which was obtained from StatsSA in South Africa. Maps were obtained for the different areas of the Vaal Triangle region and a stratified sample was compiled by taking account of the geographical distribution and concentration of people in different areas of the region. The areas were divided into different extensions and the questionnaires were distributed evenly among the inhabited sites.

A total of 401 households were interviewed by four fieldworkers. Participation rates were high (95 percent) among the households. To obtain a sample size that would supply statistically reliable results and be representative of the population of the region, the researchers relied on the experience and convention in regard to repetitive surveys conducted in the region by the Employment Research Unit (ERU), Vaal Research Group (VRG) and the Bureau of Market Research.

\section{Background}

The Vaal Triangle region is located in the southern part of the Gauteng province and the northern part of the Free State province of South Africa. The region is divided between the Emfuleni (Vereeniging and Vanderbijlpark) and the Metsimaholo (Sasolburg) municipalities.

According to the 2001 Census, the population estimate for the Vaal Triangle is 774,386, of which 658,420 reside in Emfuleni and 115,966 in Metsimaholo. The 2003 population estimate for the Vaal Triangle, based on an average annual population growth rate of 1.95 percent for the area, is 805,665 . An estimated 74.4 percent of the population (calculated from Stats SA, 2003b) resides in the townships (residential local communities).

Between 1996 and 1999 the Vaal Triangle regional economy experienced a negative real growth rate of 3.4 percent per annum (WEFA, 2001) in Gross Geographic Product (GGP). The economy recovered and has been in positive growth territory since 1999 . However, the average annual real GGP growth rate remained at a low 0.8 percent between 1999 and 2001 (calculations based on data by Global Insight, 2003: 5). Employment opportunities in the Vaal Triangle region is estimated to have fallen by 54,000 between 1991 and 1996. The manufacturing sector alone shed almost 39,000 jobs in this period (Bloch
\& Dorfling, 2000: 15). From 1996 to 2001 there was an additional decrease. of 5,473 in employment opportunities in the Vaal Triangle (calculated from Stats SA, 2003b).

Considering a real GGP growth rate that varied between a negative and a very low positive figure for the region and an estimated annual population growth rate of 1.95 percent, the rate of unemployment has been increasing - and so has poverty.

\section{Further Justification for the Study into Policy Impacts}

The majority ( 90 percent) of the unemployed in the Vaal Triangle region resides in the townships (Slabbert, 2004a: 70). Because unemployment and poverty are localised in the township areas, they require a local solution. The approach followed by the authors is twofold: an analysis of unemployment and poverty is done in the region, and then the problem is limited to a locality. Once this has been done, the authors proceed to survey the local economies' potential to supply basic production factors to itself, as well as the basic commodities consumed by it. This is done in the conscious belief that economic activity and money circulation bypasses these local economies. By creating working local economies, the burden of unemployment and poverty will be alleviated on a sustainable basis. This is also the view of the Department of Provincial and Local Government (DPLG) in its policy document "Sustainable Local Economic Development" (DPLG, 2007).

No evidence exists of previous attempts to estimate the economic impact - especially on the levels of unemployment and poverty - of this policy of strengthening and building working local economies.

Poverty, in this paper, is directly related to unemployment in an urban setting as described by Wratten (1995: 20). As poverty is one of the most imminent problems in the country in general (ANC, 1994: 14) and in the Vaal Triangle region in particular (Slabbert, 2004a: 20), emphasis is placed on the unemployed poor and (self-) employment opportunities available to them.

The skills possessed by the unemployed in the townships and products consumed by households in the townships are also surveyed. The paper estimates only the static impacts (direct, indirect and induced) of a programme of localisation. It should, however, be noted that once working local economies are created (and institutionalised) successfully, it is expected by the authors that local economic multipliers would increase and that knock-on impacts would result in more economic activity, hence having a much larger impact on poverty alleviation. 


\section{Unemployment and Poverty}

\section{Unemployment}

Because of a lack of aggregated data of households in the Vaal Triangle region, surveys were conducted by the Employment Research Unit (ERU) and the Vaal Research Group (VRG) in 1988, 1991, 1994, 1999 and 2003 to determine the unemployment and poverty rates and obtain other relevant data.

The expanded definition of unemployment, as defined by Stats SA (2000: xv), was applied to de- termine the unemployment rate in the different years. The unemployment rate (Ur) is calculated according to the standard equation:

$\frac{\text { number of unemployed }}{\text { Economically active population }(E A P)} \times \frac{100}{1}=\mathrm{Ur}$

Population statistics for the Vaal Triangle region, as calculated from data provided by Stats SA (2003b), and from the 2003 survey data (Slabbert, 2003), appear in Table 1.

Table 1: Employment and Unemployment in the Vaal Triangle Region

\begin{tabular}{|l|l|l|l|}
\hline \multirow{2}{*}{ Activity } & \multirow{2}{*}{$\begin{array}{l}\text { Numbers } \\
\mathbf{2 0 0 1}\end{array}$} & \multicolumn{2}{|l|}{$\begin{array}{l}\text { Comparison between Census and Survey } \\
\text { Data (Percent) }\end{array}$} \\
\cline { 3 - 4 } & 774,397 & 100,0 & 100,0 \\
\hline Population & & & \\
\hline $\begin{array}{l}\text { Less: } \\
\begin{array}{l}\text { Persons 0-14 years \& 65+ years of age, } \\
\text { the disabled \& economically non-active } \\
\text { population }\end{array}\end{array}$ & 410,709 & 53,0 & 52,0 \\
\hline Economically active & 363,688 & 47,0 & 48,0 \\
\hline Employed & 185,141 & 23,9 & 22,3 \\
\hline Unemployed & 178,547 & 23,1 & 25,7 \\
\hline
\end{tabular}

Using the equation (1) above, the unemployment rate (Ur) (expanded definition) for the year 2001 for the Vaal Triangle region was calculated at 49.1 percent (equation (2)).

$$
\frac{178,547}{363,688} \times \frac{100}{1}=49,1 \%
$$

The rate of unemployment in the Vaal Triangle region was higher than in any other municipal area in the Gauteng province. The average unemployment rate for the Gauteng province was 40.6 percent (calculated from Stats SA, 2003a). The unemployment rate for the Vaal Triangle region (based on 2003 survey data) was 53.6 percent.

Applying the same methodology to data from the townships of the Vaal Triangle region, Table 2 and Figure 1 provide some insight into the trend in unemployment in the region over the period 1991 to 2003.

Table 2: Trends in Unemployment Expressed as a Percentage of the Total Population and the Unemployment Rate in the Townships of the Vaal Triangle Region (Source: Slabbert, 2004b)

\begin{tabular}{|l|l|l|l|l|}
\hline Year: & $\mathbf{1 9 9 1}$ & $\mathbf{1 9 9 4}$ & $\mathbf{1 9 9 9}$ & $\mathbf{2 0 0 3}$ \\
\hline $\begin{array}{l}\text { Unemployed as percent of total popu- } \\
\text { lation: }\end{array}$ & 14,5 & 20,0 & 24,5 & 28,0 \\
\hline Unemployment rate: & 35,0 & 48,7 & 54,5 & 60,7 \\
\hline
\end{tabular}

Increases in the rate of unemployment were visible especially from 1991 to 1994 . This coincided with the abolition of the Group Areas Act. The increases might be partly explained by increased migration into the region. Unemployment increased by 73.4 percent between 1991 and 2003.

\section{Poverty}

The rate of unemployment for townships in the Vaal Triangle region for 2003 was estimated at 60.7 percent. The unemployment rate amongst the poor was 72.4 percent. The majority of the poor ( 95.7 percent) resided in the townships (Slabbert 2004a: 25). Poverty in an urban setting is directly linked to a lack of employment and failure to attain a minimum ac- 
ceptable material standard of living because of a lack of income (Wratten, 1995: 12; Novak 1996: 51). Job creation aimed at the unemployed poor in the town- ships will therefore have a direct impact on the level of poverty.

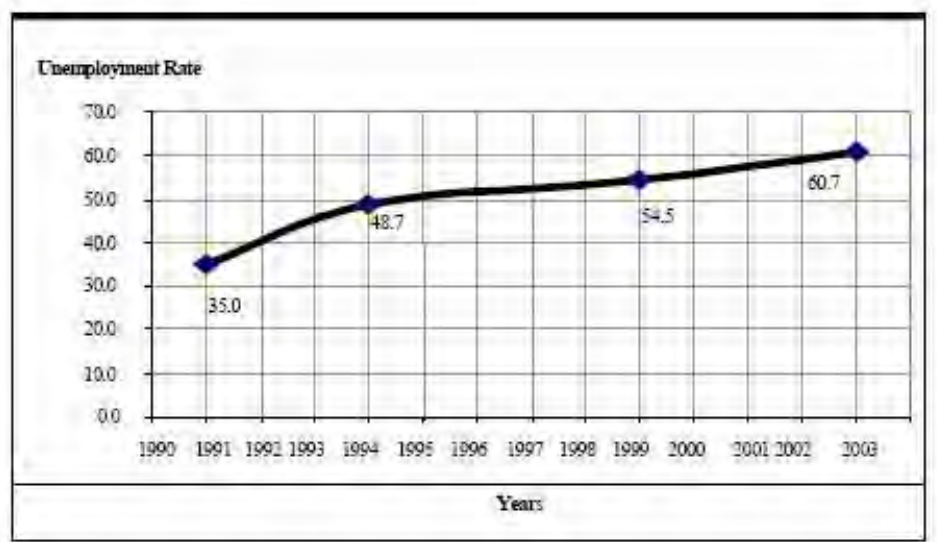

Figure 1: Trends in Rate of Unemployment - townships of the Vaal Triangle Region (Source: Constructed from Slabbert, 2003)

The 2003 survey determined the skills of the unemployed poor, as well as the economic activities they prefer to be involved in. The result of this survey is illustrated in Figure 2.

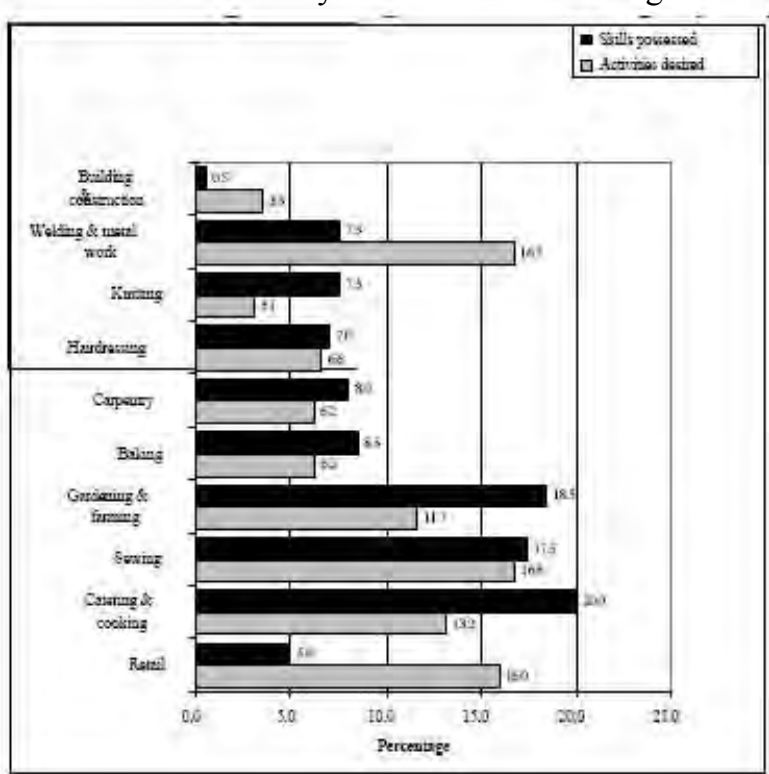

Figure 2: Skills Possessed and Activities Preferred by the Unemployed Poor: Percentage of the Unemployed Poor (2003) (Source: Slabbert, 2003)

According to Figure 2, when considering the occupations welding and metal work, 7.5 percent of the unemployed poor are skilled. However, more unemployed poor (16.7 percent) prefer to be in this occupational field. The preference for retail occupational skills among the unemployed poor by far outstrips the current available level of skills in this occupation (16 percent versus 5 percent). A large percentage of the unemployed poor skilled in the gardening and farming and the catering and cooking occupations apparently prefer to have skills in other occupational fields.

An estimate of existing skills among the unemployed poor in the Vaal Triangle region and their preferred economic activity by occupational category are illustrated in Figure 3 below. 


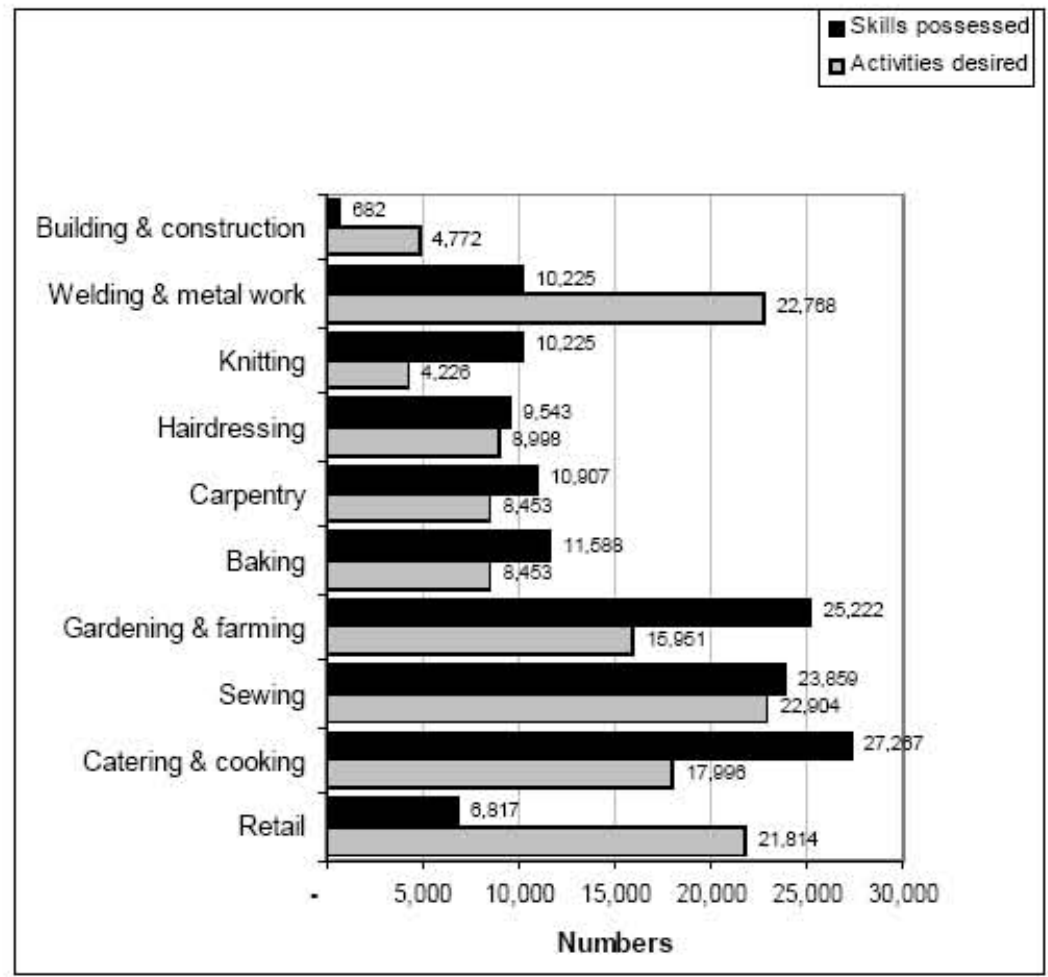

Figure 3: Skills Possessed and Economic Activities Preferred by the Unemployed Poor: Number of the Unemployed Poor (2003) (Source: Slabbert, 2003)

The 10,200 unemployed poor with skills in welding and metal work and 22,800 who would prefer to acquire skills in this occupation field open up a host of possibilities for the successful development of labour intensive downstream metal industries with a high level of beneficiation in local economies (townships) of the Vaal Triangle region. In the sewing occupation there is also a large source $(23,000)$ of available skilled labour. Although 16,000 people prefer to work in the gardening and farming occupation field, there are 25,000 people with skills in this occupation. Some respondents indicated that they prefer the gardening and farming occupation field and would acquire the relevant skills, should employment possibilities improve in this occupational field. This opens the door for government to up-scale its programme for stimulating small-scale crop gardening.

Many respondents with skills in the gardening and farming occupation revealed their preference to acquire skills in other occupations. This may be the result of a lack of opportunities to work as gardeners or insufficient wages offered by this occupation field within the region. Due largely to their absolute lack of especially financial resources, it would not be easy for the unemployed poor to initiate entrepreneurial activities in any of the occupational fields discussed above without external support.
International experience has shown that successful entrepreneurial activity usually requires intervention by local governments and development agencies in one or more of the following areas:

- Formation of cooperatives

- Access to start-up capital (finance)

- Skills training

- Search for markets

A proper skills audit among the unemployed poor in the townships may also assist in compiling a list of well qualified/skilled workers in the different occupational fields. This could assist potential investors in the region to exercise a choice of location when considering the availability of skilled/semi-skilled workers.

\section{Household Consumer Demand among the Unemployed Poor in the Townships}

The total monthly expenditure by households in the Vaal Triangle townships on five basic products is illustrated in Figure 4 (based on the 2003 survey data). These products may lend themselves to localisation as some of these production activities may be provided by cooperatives or small and micro-enterprises in the local community, using the supply of local factors of production (mainly labour). 


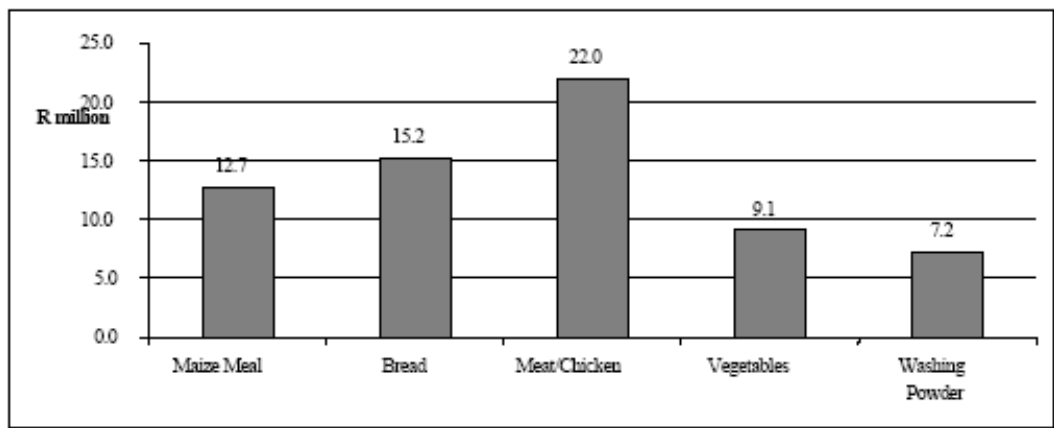

Figure 4: Monthly Expenditure on Different Products by Households in the Vaal Triangle's Townships (2003)

The combined expenditure on the five products amounts to R66.2 million per month. A simple calculation reveals that, assuming that these products could be manufactured in and around the townships and that 30 percent of the turnover (the average gross profit from similar operations) can generate income at an average wage of R600 per unemployed poor person per month (the average income currently earned by subsistence traders), the number of jobs that could be created is estimated in Table 3 below. This is a very simplistic, but practical method of estimation. In the next two sections two different impact assessment models are used to estimate the policy impact of localisation of production and consumption by the unemployed poor in the local communities of the Vaal Triangle region.

Table 3: Impact of Localisation of Production Activities on Job Creation: Vaal Triangle Townships

\begin{tabular}{|l|l|l|}
\hline Product & Number of jobs & Monthly income \\
\hline Maize Meal & 6,350 & R 3.8 million \\
\hline Bread & 7,600 & R 4.6 million \\
\hline Washing Powder & 3,600 & R 2.2 million \\
\hline Vegetables & 4,550 & R 2.7 million \\
\hline Meat & 11,000 & R 6.6 million \\
\hline Total & 33,100 & R19.9 million \\
\hline
\end{tabular}

Table 3 above gives a general indication of the impact on the job creation potential of localising production activities of some basic commodities consumed by the local community. The paper assumes that all the food is produced locally within the smallscale agricultural sector.

Although the analysis above indicates the number of jobs that could be created for certain amounts of turnover, it does not give any indication of the magnitude of investment required to localise production activities. However, due to government's deliberate policy intimation of a preference to support labour intensive job-creation schemes, it is implicitly assumed by the authors that localisation of small-scale production and small-scale farming would require considerably less investment than is required by the formal manufacturing sector, which is more capital intensive.

\section{Impact Assessment Models}

A policy of localisation is tantamount to increasing the final demand through an increase in either government expenditure (redirected public expenditure on e.g. SME development programmes or public transfers) or consumption expenditure. Thus a change in final demand (or expenditure shock) has to be introduced to the economy. This yields economy-wide (in this case regional) multiplier impacts which justify the use of a General Equilibrium Model such as a Computable General Equilibrium (CGE), InputOutput (I-O), or Social Accounting Matrix (SAM) model.

When evaluating policy impacts, it is often necessary to use the most practical and appropriate model. Organisations like the World Bank prefer using I-O models to evaluate policy impacts (also see Ebiefung \& Kostreva, 1993). This, according to the World Bank, is mainly as a result of the long periods of time required to construct e.g. macro-econometric and econometric models. Often these models take time to construct and are data intensive and not always guaranteed to provide more accurate predictions about policy impacts.

The choice of General Equilibrium Models depends on a host of factors, including data requirements, the plausibility of assumptions and the degree of computational complexity. 
The authors selected two less complicated models to illustrate the impact of localisation policy. The first is a poverty impact model designed for ease of use. The authors then constructed an I-O model for the regional economy. Both of these models are briefly outlined in this section.

\section{Poverty Impact Model}

Employment creation may supplement the existing income of households to such an extent that the headcount index for households is decreased significantly. The headcount index, which can be adapted for households (Slabbert, 2004b: 43), is defined as the fraction of the population below the poverty line (Deaton, 1994: 122). The poverty gap measures the average shortfall of the income of the poor from the poverty line (Sen, 1981: 24-34). The Household Subsistence Level (Potgieter, 2003: 69) is used as a poverty line in this study.

If the number of unemployed persons in a household is described by $u i$, and employment opportunities can be created at an average wage level of $\mathrm{W}$, the poverty gap $G i$ of a single household can be reduced by $u i W$, which results in a new poverty gap of:

$$
G_{i}-\left(u_{i} W\right)
$$

Where:

$G i=$ the poverty gap of a single household; $u i=$ the number of unemployed members in a household;

$W=$ the average wage earned by unemployed members of households as a result of an employment creation scheme.

An employment creation scheme aimed at the unemployed poor would have an immediate effect on the extent of poverty, because it reduces the poverty gap. However, to have a significant impact, it should reduce the headcount index. The extent to which the headcount index is reduced would indicate the success of an employment creation programme. The headcount index can only be reduced if one condition holds - the poverty gap of a household or households has to become zero or negative. This condition is described by the following equation:

$$
G_{i}-\left(u_{i} W\right) \leq 0
$$

Where:

$$
G i=\text { the poverty gap of a single household }
$$

$u i=$ the number of unemployed members in a household

$W=$ the average wage earned by unemployed members of households as a result of an employment creation scheme

The larger the number of households satisfying this condition, the smaller the headcount index.

\section{Input-Output (I-O) Model}

An I-O model is selected because accurate data for the local communities is usually unavailable, unattainable or unreliable. The only data available regarding the regional economy is that contained in the ten sector Input-Output Table. In respect of the local communities (townships) within the region, very little economic data obtained during the last Census is available, often excluding important economic variables. In this study, the authors were thus limited to regional economic data as contained in the ten sector Input-Output Table, which was supplemented by key statistics on unemployment, poverty, labour supply and consumption expenditure of local community members, supplemented by Census data obtained from Stats SA.

The transactions tables contain only data on the flow of goods and services among the supplying and buying sectors. It does not provide the analyst with very detailed disaggregated data. Payment flows among different economic actors (institutions) such as government, households and firms usually contained in the SAM, is not compiled for the region. This limits the authors to the estimation of the impact of final demand changes such as public expenditure and private consumption expenditure shocks and its impact on local employment and level of poverty.

The authors thus elected to use an I-O model with the following restrictive assumptions ${ }^{1}$ :

1. No economy and diseconomy of scale in sectors involved

2. Prices are constant

3. No substitution between inputs of production

4. Demand for final goods and services are exogenous

To study the impact of a policy of localisation, the authors introduce a shock in the demand for final goods and analyse its impact on total production and multiplier effects. This is motivated by the fact that expression to a policy of localisation may be given in a variety of forms: government may increase

For extensive review of merits and limitations of I-O model see Heady and Carter (1959), Ebiefung and Kostreva (1993) and Tiebout (1957). 
welfare transfers ${ }^{2}$ or localise the receipt and expenditure of welfare payments, redirect current expenditure by local community households through a deliberate policy of stimulating local markets, or localise the extended public works programme. Many more policy programmes that alter the final demand, would have a similar impact on the local and regional economy.

By using a basic input-output model in the form:

$$
\Delta \mathrm{X}=(\mathrm{I}-\mathrm{A})^{-1} \Delta \mathrm{F}
$$

Where:

$\Delta \mathrm{X}=$ Change in Total Production (output)

$\mathrm{I}=$ Identity matrix

$\mathrm{A}=$ Direct coefficient matrix

$\Delta \mathrm{F}=$ Change in final demand

it is, for example, possible to estimate the impact of localising the basic annual consumption expenditure of R794.4 million (basic food and washing powder in the townships) by households, obtained from the survey on income. Similarly, the model may be used to estimate the impact of a change in final demand as a result of any policy that would see an increase in government expenditure in the local community and its impact on income.

Because the food sector is not measured separately in the input-output table for the Vaal economy, it is further assumed that food is produced within the agricultural sector ( i.e. locally) and takes on the multiplier of the agricultural sector, which is also quite low for the regional economy. This is only plausible if it is accepted that, by localising the current economic activity of the townships, it would take on multipliers similar to those in the Vaal region, within which it is based. This is quite plausible in the long term.

\section{Summary of Results from the Policy Impact Analysis}

\section{Poverty}

The 2003 household survey data is used to determine the impact of job creation on poverty in the Vaal Triangle. A poverty impact model (Slabbert, 2004b: 54-58) is used in Figure 5 below to demonstrate that, if all the unemployed poor in the townships of the Vaal Triangle could be gainfully employed in occupations that provide them with a monthly income of R600, the percentage of poor households would decrease from 61.6 to 27.6 percent.

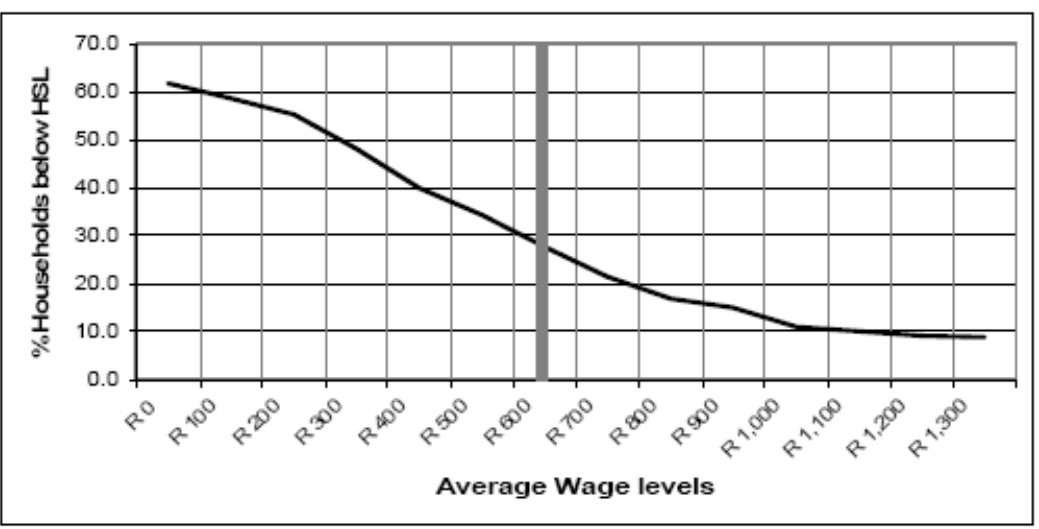

Figure 5: Impact of Job Creation at an Average Wage Level of R600 per Month on Poverty Levels in the Townships of the Vaal Triangle

\section{Policy Impacts of Localisation}

As explained earlier in this paper, most of the income in the townships is earned outside of the township economy. The same goes for consumption expenditure. Reynolds (2004) therefore estimated the expenditure multiplier in townships of South Africa to be around unity. In this section, the authors make use of a regional input-output model based on the 2000 input-output table for the Vaal economy (Table 4 - appendix) to estimate the impact of localising the manufacture of consumables mostly used by households in the townships. It was estimated that households in the townships spend a total of R66,2 million per month on basic food and washing powder, which relates to R794.4 million per annum.

By using the input-output model discussed above, the impact of a change in final demand of R794.4 million is inferred. This is the amount currently spent by the unemployed poor on basic commodities. The rationale is that, with the right policy, it is possible 
to localise this total expenditure if all is produced within the same locality. As explained above, it is expected that locally produced food would take on the multiplier of the agricultural sector, which is also quite low for the regional economy.

Making use of the Leontif Inverse Matrix (Table 6 - appendix) of the Vaal regional economy and equation (5), it is estimated that, by localising only the five items most consumed by poor households in the township, an additional gross output of R953.28 million is created annually within the township economy. This is based on the low regional multiplier for agriculture, but includes the direct, indirect and induced impacts on the change in final demand assumed to emanate from the agricultural sector.

The backward linkages of the agricultural sector show weak industrial linkage. This implies that the sector depends on local raw materials for only 9.6 percent of its total requirement. Even when labour is included, the agricultural sector depends on the local economy for only 16.4 percent of its local input. A total of 73.8 percent of its input is imported either from other South African provinces or the rest of the world. With regard to the forward linkages, 60.2 percent of agricultural output is sold to the local economic sectors. Local manufacturing enterprises contribute 97.9 percent (calculated from Table 5) towards agricultural intermediate output. This shows potential for further development and diversification. An effort to improve agricultural output would bring about a reduction in import of agricultural products and stimulate the manufacturing sector, provided that problems with irregular rainfall is addressed through improved technological and agricultural practices and investment in agricultural infrastructure, like irrigation. Considerable potential exists for the development of small scale garden agriculture, which is usually within reach of the poor.

\section{Multiplier Effect}

Incentives for expanding the formal agricultural sector may be less effective in boosting income earned by households, employment creation and output than would be the case in other sectors. An increase of R1,000,000 in the formal agricultural sector's final demand would increase

- income earned by households by R111,000;

- the contribution to the GGP by R240,000;

- the outflow of money due to rising imports by R861,000;

- job opportunities by an additional 8 throughout the Vaal economy.

Based on the above, the formal agricultural sector has only a limited ability to improve household in- come and to stimulate some growth in the manufacturing sector. However, ample opportunity exists for the development of the informal agriculture, which has the ability to supplement the income of poor households.

\section{Conclusions}

The socio-economic analysis of local township communities in the Vaal Triangle indicates that local township communities are worse off in respect of unemployment and poverty than the ten preceding years in spite of the national economy benefiting from the gains of globalisation. This indicates the need for alternative policy and programmes of action in respect of employment creation methods and poverty alleviation. The formal sector economy evidently cannot provide sufficient employment opportunities for the growing population and labour force. Current consumption of food volumes by households in the townships suggest that there is room for introducing programmes to assist the unemployed poor in producing their own consumption requirements locally, with surplus unemployed labour available to them within their own local communities. The impact that such a programme would have is estimated to substantially increase income in the township. Deliberate government intervention is, however, required - for example assistance in establishing cooperatives (e.g. a milling cooperative or a soap manufacturing cooperative, etc.), training, credit extension and SME development support. This is expected to provide a further stimulus to final demand in the local (township) economy.

According to a poverty impact model, job creation programmes can alleviate poverty to a large extent within townships of the Vaal Triangle. This is illustrated by the simulated localisation of some economic activity, creating relatively low wages aimed at the unemployed poor. The paper also briefly focuses on the extent to which localisation of some economic activity, like getting local residents to buy from their own community, might increase final demand and hence impact on production (output). The authors estimate this impact using the input-output model for the Vaal Triangle.

This paper presents the first attempt to illustrate the prospective benefits arising from a policy of localisation of economic activity. Because of a complete lack of reliable data on local communities, the authors have used survey results and combined it with a regional input-output model to illustrate that localisation of economic activity (production and consumption) could substantially increase the level of output (income) within local economies. Localisation could thus contribute toward the achievement 
of the Millennium Development Goals, halving unemployment and poverty by 2014 .

Being mindful of the limitations of this paper, the authors recommend the following actions by policy makers in South Africa:

- The methodology used to measure unemployment and poverty should be tested and tried in collaboration with StatsSA; the authors recommend that, upon final acceptance by StatsSA, unemployment and poverty measurements should be extended to all local communities (townships).

- Pilot studies should be undertaken in a number of priority regions to supplement regional inputoutput tables with accurate measurements of the economic flows within the different economic sectors of the township economies. Repetitive policy impact analyses should furthermore be conducted.

- Pilot projects should be undertaken to localise welfare payments and expenditure of same, production and consumption activity and current government programmes aimed at job creation and the alleviation of poverty, for example SME development, formation of cooperatives, extended public works programmes, etc. Proper monitoring and evaluation, as well as measurement of the policy impacts on unemployment, poverty and local income levels, will be crucial for these pilots to be successful and to make a real contribution to the policy debate of an optimal institutional framework within which policy is applied.

\section{References}

1.ANC (African National Congress). (1994) The Reconstruction and Develop ment Program (RDP), Johannesburg.

2.BASU, K. (2003) Globalization and marginalization: Re-examination of development policy , BREAD working paper No. 026, Bureau for Research in Economic analysis of Development: Cambridge, Massachusetts.

3.Bloch, R. \& Dorfling, T. (2000) Vaal Region: Industrial Regeneration Potential, Final Report, Johannesburg: Office for Metropolitan and Industrial Research.

4.Deaton, A. (1994) The analysis of household surveys: Microeconomic analysis for development policy, Princeton: Princeton University.

5.DPLG. (2007) Sustainable Local Economic Development: Policy Document. Department of Provincial and Local Government, Republic of South Africa, Pretoria.

6.EBIEFUNG, A. and KOSTREVA, M. (1993) The generalized Leontief input-output model and its application to choice of new technology, Annals of operation research, Vol. 44: 161-172.

7.GLOBAL INSIGHT (2003) in Economic Regeneration Summit, 30 October 2003, Sedibeng.

8.HEADY, O.E. and CARTER, O.H. (1959) Input-output model as techniques of analyis for interregional competition. Journal of Farm Economics, 41(5), 978-991.

9.HELLEINER G.K. (2001) Markets, politics and globalization: Can the global economy be civilized? Journal of human development. Vol. 2(1): 23-33.

10.Nel, h. (2001) Technical coefficients, Leontief Inverse Matrix and Sectoral Multipliers for the Vaal. Unpublished research document. Vaal Research Group. Vanderbijlpark.

11.NOVAK, M. (1996) “Concepts of poverty”, in Øyen, E., Miller, S.M. \& Samad, S.A., eds. Poverty: A global review, Oslo: Scandinavian University Press.

12.NAYYAR, D. (2002) Governing globalization: Issues and institutions. Oxford, Oxford university press.

13.PELUPESSY, W. \& SLABBERT, T.J.C. (2001) "Employment creation in SA townships: An Emfuleni case study", Africa Insight, 31(4): 35 - 45.

14.Potgieter, J.F. (2003) Household subsistence level in the major cen tres of the RSA, September 2003, Report 6/2003, Port Elizabeth: Health and Development Research Institute.

15.REYNOLDS, N. (2004) Periodic Markets Handbook. Unpublished. Johannesburg.

16.SEN, A. (1981) Poverty and famines - an essay on entitlements and deprivation, New York: Oxford University Press.

17.Slabbert, T.J.C. (2003) Unpublished results of a household survey conducted in July 2003 in Emfuleni and Metsimaholo, Vanderbijlpark.

18.Slabbert, T.J.C. (2004a) A Micro-economic analysis of unemployment, poverty and other socio-economic \& environmental issues in the Vaal, Research Report no. 13, Vanderbijlpark: Vaal Research Group.

19.Slabbert, T.J.C. (2004b) An investigation into the state of affairs and sustainability of the Emfuleni economy, Pretoria: Unpublished DCom dissertation, University of Pretoria.

20.Stats sa (Statistics South Africa) (2000) October Household Survey 1999, Statistical Release P0317, Pretoria: Government Printer.

21.Stats sa (Statistics South Africa) (2003a) Census 2001: Census in brief, Pretoria: Government Printer.

22. Stats sa (Statistics South Africa) (2003b) (KevinP@statssa.gov.za) Census 2001 data provided by Kevin Perry from Statistics South Africa, [E-mail to:] Slabbert, T.J.C. (vrg@telkomsa.net) 24 Nov.03.

23.TIEBOUT, M.C. (1957) Regional and inter-regional input-output models: An appraisal, Southern Economic Journal, 24(2), 140-147.

24.UNDP, (2007) 2007 Annual Report: Inclusive Globalisation. Available online at http://www.undp.org/publications /annualreport2007/inclusive_globalization.shtml Acessed 16 August 2008. 
25.VAN ZYL, J.C. and REYNOLDS, N. (2006). Workshop held by The Peoples Agenda, 13 September 2006, Midrand Johannesburg.

26.WEFA (Wharton Economic Forecasting Associates) (2001) Projections of GGP growth rates for Emfuleni at constant 1995 prices for 1990 - 2000, Pretoria. Data provided by Whiteford, A. (andrew@dri-wefa.co.za). [E-mail to:] Slabbert, T.J.C. (vrg@telkomsa.net)1 October 2001.

27.WRATTEN, E. (1995) “Conceptualising poverty”, Environment and Urbanization, Vol. 7(10): 11-36. 


\section{Appendix}

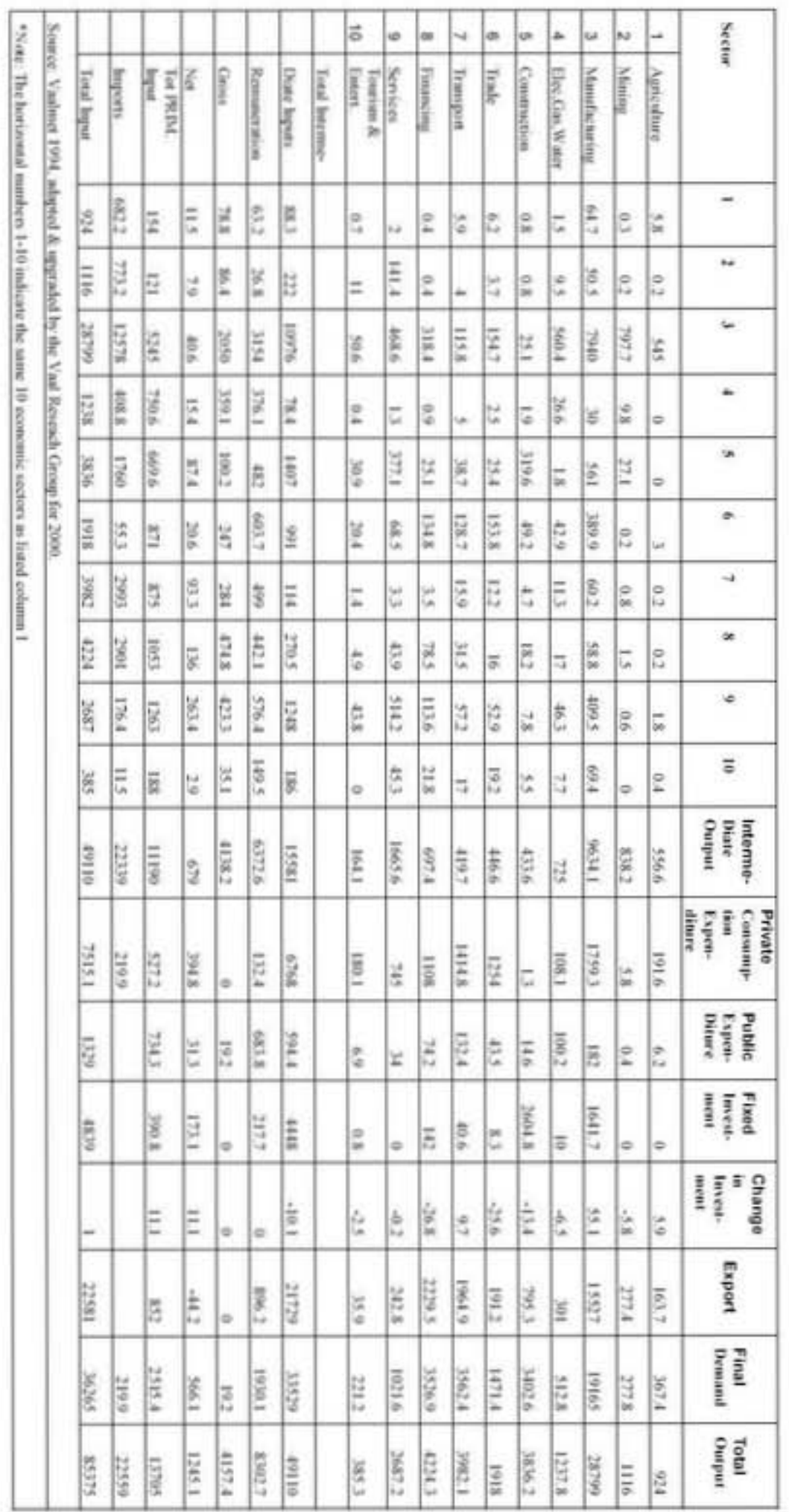


Table 5: Technical Coefficients of the Vaal Triangle Economy (2000)

\begin{tabular}{|l|l|l|l|l|l|l|l|l|l|l|}
\hline Sector* & $\mathbf{1}$ & $\mathbf{2}$ & $\mathbf{3}$ & $\mathbf{4}$ & $\mathbf{5}$ & $\mathbf{6}$ & $\mathbf{7}$ & $\mathbf{8}$ & $\mathbf{9}$ & $\mathbf{1 0}$ \\
\hline 1 Agriculture & 0.0063 & 0.0002 & 0.0189 & 0.0000 & 0.0000 & 0.0016 & 0.0001 & 0.0000 & 0.0007 & 0.0010 \\
\hline 2 Mining & 0.0003 & 0.0002 & 0.0277 & 0.0079 & 0.0071 & 0.0001 & 0.0002 & 0.0004 & 0.0002 & 0.0000 \\
\hline 3 Manufacturing & 0.0700 & 0.0453 & 0.2757 & 0.0242 & 0.1462 & 0.2033 & 0.0151 & 0.0139 & 0.1524 & 0.1801 \\
\hline 4 Elect. Gas \& Water & 0.0016 & 0.0085 & 0.0195 & 0.0215 & 0.0004 & 0.0224 & 0.0028 & 0.0040 & 0.0172 & 0.0200 \\
\hline 5 Construction & 0.0009 & 0.0007 & 0.0009 & 0.0015 & 0.0853 & 0.0257 & 0.0012 & 0.0043 & 0.0029 & 0.0143 \\
\hline 6 Wholesale, Retail & 0.0067 & 0.0033 & 0.0054 & 0.0020 & 0.0066 & 0.0802 & 0.0031 & 0.0038 & 0.0197 & 0.0498 \\
\hline 7 Transport & 0.0064 & 0.0036 & 0.0040 & 0.0040 & 0.0101 & 0.0671 & 0.0040 & 0.0075 & 0.0213 & 0.0441 \\
\hline 8 Financing & 0.0004 & 0.0004 & 0.0110 & 0.0007 & 0.0065 & 0.0703 & 0.0008 & 0.0186 & 0.0422 & 0.0565 \\
\hline 9 Services & 0.0022 & 0.0004 & 0.0163 & 0.0011 & 0.0983 & 0.0357 & 0.0008 & 0.0104 & 0.1914 & 0.1176 \\
\hline $\begin{array}{l}\text { 10 Tourism \& Entertain- } \\
\text { ment }\end{array}$ & 0.0008 & 0.1267 & 0.0018 & 0.0003 & 0.0081 & 0.0106 & 0.0004 & 0.0012 & 0.0163 & 0.0000 \\
\hline Labour & 0.0683 & 0.0240 & 0.1095 & 0.3038 & 0.1256 & 0.3146 & 0.1252 & 0.1047 & 0.2145 & 0.3867 \\
\hline Source: Nel 2001. & \multicolumn{9}{|l|}{} \\
\hline *Note: The horizontal numbers 1-10 indicate the same 10 economic sectors as listed column 1 & \\
\hline
\end{tabular}

Table 6: Leontief Inverse Matrix of the Vaal Triangle Economy (2000)

\begin{tabular}{|l|l|l|l|l|l|l|l|l|l|l|l|l|}
\hline \multicolumn{2}{|l}{ Leontief Inverse } & \multicolumn{6}{|l|}{ Direct +Indirect+Induced } & \multicolumn{1}{l|}{} & & \\
\hline & SECTOR & 1 & 2 & 3 & 4 & 5 & 6 & 7 & 8 & 9 & 10 & 11 \\
\hline 1 & Agriculture & 1.012 & 0.005 & 0.151 & 0.008 & 0.002 & 0.030 & 0.031 & 0.023 & 0.023 & 0.005 & 0.113 \\
\hline 2 & Mining & 0.006 & 1.005 & 0.151 & 0.018 & 0.003 & 0.029 & 0.032 & 0.029 & 0.178 & 0.016 & 0.110 \\
\hline 3 & Manufacturing & 0.035 & 0.042 & 1.499 & 0.037 & 0.004 & 0.054 & 0.057 & 0.060 & 0.071 & 0.011 & 0.233 \\
\hline 4 & Elec, Gas, Water & 0.015 & 0.015 & 0.214 & 1.036 & 0.005 & 0.081 & 0.091 & 0.074 & 0.066 & 0.013 & 0.411 \\
\hline 5 & Construction & 0.015 & 0.019 & 0.378 & 0.018 & 1.094 & 0.066 & 0.075 & 0.067 & 0.184 & 0.020 & 0.275 \\
\hline 6 & Trade & 0.027 & 0.017 & 0.577 & 0.052 & 0.036 & 1.199 & 0.196 & 0.185 & 0.148 & 0.030 & 0.560 \\
\hline 7 & Transport & 0.006 & 0.003 & 0.096 & 0.009 & 0.003 & 0.036 & 1.040 & 0.032 & 0.028 & 0.006 & 0.170 \\
\hline 8 & Financing & 0.006 & 0.003 & 0.092 & 0.010 & 0.006 & 0.034 & 0.041 & 1.047 & 0.038 & 0.006 & 0.153 \\
\hline 9 & Services & 0.021 & 0.014 & 0.469 & 0.043 & 0.009 & 0.113 & 0.123 & 0.138 & 1.315 & 0.034 & 0.436 \\
\hline 10 & Tourism \& Entertainment & 0.029 & 0.018 & 0.589 & 0.052 & 0.024 & 0.185 & 0.191 & 0.188 & 0.257 & 1.023 & 0.651 \\
\hline 11 & Households & 0.044 & 0.017 & 0.556 & 0.042 & 0.010 & 0.246 & 0.271 & 0.229 & 0.194 & 0.038 & 1.293 \\
\hline & Total & 1.2 & 1.2 & 4.8 & 1.3 & 1.2 & 2.1 & 2.1 & 2.1 & 2.5 & 1.2 & 4.4 \\
\hline Source: Nel 2001. & & & & & & & & \\
\hline$*$ Note: The horizontal numbers $1-10$ & indicate the same 11 economic sectors as listed column 1 & \\
\hline
\end{tabular}

\section{About the Authors}

Prof. Marthinus C Breitenbach

Martin Breitenbach has been teaching economics for 18 years. He is currently an associate professor of economics at the School of Economics at the University of Pretoria. He has published extensively and has persented many international conference papers. He has had visiting professorships at the Molde University College, Norway and The universities of Corvinus, Budapest, Miskolc University and Szent Istvan University in Hungary. His current research focus is Economic Impact Assessment. 
Prof. Tielman JC Slabbert

Professor Slabbert is an expert on poverty measurement and Economic Impact Assessment. He has published extensively and completed many studies of the Vaal region economy in South Africa. He teaches at North-West University and has a long-standing relationship with Molde University, Norway, where he has been visiting professor on many occasions. 